\title{
A CONTEXT-BASED APPROACH TO SCIENCE TEACHING
}

\author{
Jack Holbrook \\ University of Tartu, Estonia
}

It has been traditional to educate students in school, especially secondary schools, through subject domains and within lessons named according to the domain. Today in most countries, science lessons are offered in the curriculum, specified as science, or one of its sub-components e.g. biology, chemistry, physics, or perhaps a combination of these e.g. physical science. It does not have to be this way, of course, as can be amplified by the concept of an integrated day, implemented at the primary level in a number of countries.

So what is intended in science lessons? A traditional view is that they are about information and concepts so as to provide an intellectual background for further subject learning at a higher level. This especially came about when education was selective and not all students were able to successfully compete for the opportunity to progress to the higher levels of learning. But even today, in systems where education is intended for all (and usually compulsory up to $15 / 16$ years of age), content knowledge and conceptual understanding seems to prevail. One look at the standard science textbook will show chapter headings dominated by the subject and with heavy use of scientific terminology.

Today, however, we are very aware of two major shortcomings associated with such an approach:

a) The science content keeps increasing and increasing at a greater and greater pace (sometimes describe as exponential).

b) School science has both an obligation to the subject and also to the need for education within a modern society, where increasingly technology provides the visible face of science and issues associated with technology within the society bring science into both an interdisciplinary focus and into playing a role in the decision-making processes within society.

Clearly to tackle the first, we are forced to pick and choose. Do we need to study classification systems in biology? Is the periodic table really a basis for studying chemistry when organic chemicals dominate the modern technological advances in the material world? Do we need to promote mathematical approaches to phenomena when, in today's world, the computer has overtaken such needs. But is simply picking and choosing topics to include too arbitrary and not the approach we should adopt? Is there a need to pause and reflect on the role of science teaching in the modern world? In fact, is it not the second shortcoming where teachers and science educators need to turn their attention in order to deal with the first aspect?

Students go to school to be educated. And by that I presume we mean educated for the world of today and tomorrow. Surely we don't mean educating students for yesterday's world, when steel was made using the open hearth method, or bond lengths were calculated in terms of Angstrom units, or navigational processes ignored GPS. And by the same token, surely we don't mean learning abstract science without any recourse to the related technology, or even the issues or uncertainties faced by the modern world, e.g. global warming, the use of genetically modified foodstuffs, or spectroscopic ways of analysis.

In fact, science in schools cannot be taken to be the learning of content in isolation of the context in which it appears. That context needs to be the society. This means the teaching in science lessons needs to encompass the skills, attitudes and values that enable the scientific conceptual links to be relevant for today's world. Goodbye content-only science teaching. That is yesterday's world. Today, science teaching needs to be context driven, providing relevance to science conceptual learning and ensuring the scientific ideas are interrelated to society factors, whether these are collaborative working, adaptability to the situation, or making decisions based on factors that can culturally vary.

So what is the bottom line? Science education, the teaching in school under the science curriculum label, is not scientist's science. Actually it never was. But in the heydays of yesteryears, when science occupations were being 
cherished, many teachers formed the mistaken opinion that it was only the science subject content that mattered. And the result of such a vision, in Europe today, is that students like science, but not that offered in schools - this provision tends to lack relevance (Teppo \& Rannikmae, 2008). Today's society wants competent people. Europe wants school curricula to be competence-based. Yet, of course, competent individuals are not developed using obsolete learning techniques, narrow approaches that do not promote creative or innovative thinking, communicative abilities, or collaborative actions.

But are these the attributes which science teaching in schools are promoting? One look at the assessment systems in common use in science learning is enough to show that the acquisition of content seems to be all that matters. And all this despite the SSI (socio-scientific issue) movement and the value placed on argumentation skills, the IBSE (inquiry-based science education) movement and the need to develop creative thinking in areas like planning meaningful ways to solve problems in an evidence-based manner, or the need to be aware of Engineering Practices and having a meaningful appreciation of the Nature of Science.

Maybe the developments now being suggested in the US are the way to go (NRC, 2012). The next generation science standards (NRC, 2013) recognise the overarching need is for all students to:

- $\quad$ have some appreciation of the beauty and wonder of science;

- $\quad$ possess sufficient knowledge of science and engineering to engage in public discussions on related issues;

- be careful consumers of scientific and technological information related to their everyday lives;

- be able to continue to learn about science outside school; and

- possess the skills to engage in careers of their choice, including (but not limited to) careers in science, engineering, and technology.

And to achieve these, NRC point to three overarching needs:

a) Science and engineering practices covering abilities to:

- Asking questions (for science) and defining problems (for engineering).

- Developing and using models.

- Planning and carrying out investigations.

- Analysing and interpreting data.

- Using mathematics and computational thinking.

- Constructing explanations (for science) and designing solutions (for engineering).

- Engaging in argument from evidence.

- Obtaining, evaluating and communicating information.

b) Cross cutting concepts such as:

- Patterns.

- Cause and effect: mechanism and explanation.

- Scale, proportion and quantity.

- Systems and system models.

- Energy and matter: Flow, cycles and conservation.

- Structure and function.

- Stability and change.

c) Core Science concepts within fields such as:

- Physical Science (for example, Matter and its interactions; Motion and stability: Forces and interactions: Energy: Waves and their applications in technologies for information transfer)

- Life Science (for example, From molecules to organism: Structures and processes: Ecosystems: Interactions, energy and dynamics: Heredity: Inheritance and variety of traits: Biological evolution: Unity and diversity)

- $\quad$ Earth and Space Science (for example, Earth's place in the universe: Earth's systems: Earth and human activity

- Engineering, Technology and Applications of Science (for example, Engineering Design: Links among engineering, technology, science and society) 
The above seems to be very far from the traditional content approach. Engineering and technology are strongly embraced, defined (NRC, 2012) in broad ways and are included in the framework for several reasons.

i. allowing students to explore the practical use of science, given that a singular focus on the core ideas of the disciplines would tend to short change the importance of society relatedness;

ii. ensuring inclusion, at the compulsory school levels, topics which do not typically appear elsewhere in the curriculum;

iii. providing a context in which students can test their own developing scientific knowledge and apply it to practical problems, thus enhancing their understanding of science-and, for many, their interest.

"Science is not just a body of knowledge that reflects current understanding of the world; it is also a set of practices used to establish, extend, and refine that knowledge" (NRC, 2012).

For students to develop a sustained attraction to science and to appreciate the many ways in which it is pertinent to their daily lives, NRC (2012) suggest that classroom learning experiences in science need to connect with their own interests and experiences. Goodbye to the content-only approach. It is time for science education to embrace learning suitable for the modern world.

\section{References}

National Research Council. (2012). A Framework for K-12 Science Education: Practices, Crosscutting Concepts, and Core Ideas. Committee on a Conceptual Framework for New K-12 Science Education Standards. Board on Science Education, Division of Behavioral and Social Sciences and Education. Washington, DC: The National Academies Press.

National Research Council. (2013). Next Generation Science Standards. Board on Science Education, Division of Behavioral and Social Sciences and Education. Washington, DC: The National Academies Press.

Teppo, M. \& Rannikmae, M. (2008). Paradigm Shift for Teachers: More Relevant Science Teaching. In: Jack Holbrook, Miia Rannikmae, Priit Reska \& Paul Ilsley (Eds.). The need for a paradigm Shift in Science Education for Post-Soviet Societies. Germany: Peter Lang.

Jack Holbrook PhD., Visiting Professor, Science Education Centre, University of Tartu, Vanemuise St. 46-226, Tartu 51014, Estonia.

E-mail: jack.holbrook@ut.ee

Website: https://www.ut.ee/biodida/e/inimesed.htm\#Jack 